\title{
PENGARUH SUPLEMENTASI Fe DAN Zn TERHADAP KADAR HAEMOGLOBIN DAN KESEGARAN JASMANI PADA LANSIA ANEMIA DI KABUPATEN BANTUL
}

\author{
Endang Pamungkasiwi ${ }^{1}$, Wiryatun Lestariana ${ }^{2}$, Retno Pangastuti ${ }^{3}$
}

Background: Province of Yogyakarta Special Territory is a province of "elderly" structure population, as viewed from the number of elderly which is $15 \%$ of total population. Anemia is one of nutrition problems of elderly which reaches as high as $50 \%$. This is caused by low intake of iron and other substances related to iron metabolism process in forming hemoglobin. Low hemoglobin concentration can be one of causes of elderly declining physical fitness. Efforts to overcome anemic problems can be done through the supply of iron and zinc for the elderly twice a week.

Objective: To know effect of iron and zinc supply to hemoglobin concentration and physical fitness for anemic elderly at Bantul District, Province of Yogyakarta Special Territory.

Methods: The study was a randomized double blind controlled trial design. Subject of the study were anemic elderly that fulfilled inclusion criteria. The supply of iron, combination of iron and zinc to trial group was given twice a week on different days, supply of iron was given on Monday and Thursday, while supply of zinc was given on Tuesday and Saturday. Laboratory and physical fitness examination to both group were done prior and after treatment. Nutrition intake data were achieved through food record. Next, to know effect of iron, iron and zinc supply to elderly hemoglobin concentration and physical fitness, covariant analysis was done.

Results: The result of the study showed that after 3 months' treatment, there was significant difference of hemoglobin concentration caused by different treatment of group with iron supply, iron and zinc combination supply and control group ( $p=0.012$ ) although iron and combined iron and zinc supply had equal effectiveness in increasing hemoglobin concentration ( $p=0.404)$. There was no significant relationship between elderly hemoglobin concentration and physical fitness $(p=0.448)$. This showed that treatment given affected increase of hemoglobin concentration but the supply and increase of haemoglobin concentration did not affect increase of elderly physical fitness.

Conclusion: The supply of iron and combined iron and zinc increase hemoglobin concentration, but the supply and increase of hemoglobin concentration did not increase the elderly physical fitness.

Key words: Iron and iron supply, anemia, physical fitness, elderly

\section{PENDAHULUAN}

Pada tahun 2000 beberapa provinsi di Indonesia secara demografis telah masuk kategori memiliki penduduk berstruktur tua dengan proporsi warga lanjut usianya mencapai 7\% ke atas. Kelima propinsi tersebut adalah: Daerah Istimewa Yogyakarta $(13,72 \%)$, Jawa Timur $(10,54 \%)$, Bali $(9,79 \%)$, JawaTengah $(9,55 \%)$, Sumatera Barat $(9,06 \%)$, dan Sulawesi Selatan (7,63\%). Ternyata sebagian besar warga usia lanjut terdapat di Pulau Jawa, dan angka harapan hidup tertinggi dicapai Propinsi DIY yang sudah dapat mencapai 68 tahun untuk laki-laki dan 70 tahun untuk perempuan, serta penduduk lanjut usianya sudah mencapai $15 \%$ dari jumlah penduduk (3,5 juta jiwa) (1).

Bertambahnya lansia, menimbulkan permasalahan tersendiri, termasuk masalah kesehatan. Anemia merupakan salah satu masalah kesehatan pada lansia yang prevalensinya cukup tinggi, hasil Survey Kesehatan Rumah Tangga menjumpai masalah anemia pada usia $>60$ tahun sebesar $59,8 \%$ pada laki-laki dan $49,8 \%$ pada perempuan (2).

Anemia didefinisikan sebagai suatu keadaan kadar hemoglobin dalam darah rendah dari normal untuk orang yang bersangkutan (3). Batasan Anemia menurut WHO apabila hemoglobin $<12 \mathrm{gr} / \mathrm{dl}$ pada wanita dan $<13 \mathrm{gr} / \mathrm{dl}$ pada laki-laki (4).

Dengan berkurangnya hemoglobin sebagai alat angkut oksigen, maka "jatah" oksigen untuk otot berkurang. Untuk menyesuaikan dengan berkurangnya jatah oksigen, maka otot membatasi produksi energi. Akibatnya mereka yang anemia akan cepat lelah bila bekerja karena cepat kehabisan energi. Maka kondisi penderita anemia akan mempunyai tanda-tanda " 5 L" (letih, lemah, lesu, lelah, lunglai) (5).

Salah satu alternatif yang dapat dilaksanakan untuk menanggulangi terjadinya anemia adalah dengan pemberian suplementasi Fe. Dari beberapa hasil penelitian pada beberapa kelompok umur pemberian suplemen Fe untuk menaikan kadar hemoglobin akan efektif apabila dikombinasi dengan beberapa vitamin dan mineral lain serta protein yang cukup (6).

\section{BAHAN DAN METODE}

Penelitian ini adalah studi eksperimen murni yang dilakukan secara acak sederhana tersamar ganda dengan kontrol (double blind randomized controlled trial).

\footnotetext{
1 Dinas Kesehatan Propinsi DIY

2 Bagian Biokimia Fakultas Kedokteran UGM, Yogyakarta

3 Instalasi Gizi RS Dr. Sardjito/Fakultas Kedokteran UGM, Yogyakarta
} 
Subjek penelitian adalah lansia yang tinggal di wilayah kerja dan tercatat di Posyandu Puskesmas Jetis I, Puskesmas Sewon II, dan Puskesmas Imogiri II, Kabupaten Bantul dan memenuhi kriteria inklusi: berumur $\geq 60$ tahun, tidak sedang menderita penyakit kronik dan penyakit akibat perdarahan dari hasil pemeriksaan fisik oleh dokter, penderita anemia dengan kadar $\mathrm{Hb}$ antara > $\mathrm{gr} / \mathrm{dl}-12 \mathrm{gr} / \mathrm{dl}$ untuk wanita dan kadar $\mathrm{Hb}$ antara $>8 \mathrm{gr} / \mathrm{dl}-13 \mathrm{gr} / \mathrm{dl}$ untuk lakilaki, mengikuti kegiatan aktivitas fisik minimal 2 kali sebulan dan bersedia berpartisipasi dalam penelitian.

Berdasarkan hasil penapisan dari 614 lansia yang memenuhi kriteria inklusi adalah 148. Dari 148 lansia diambil secara acak untuk sampel sebanyak 120 lansia. Selanjutnya dilakukan randomisasi blok di tingkat individu, untuk memasukan ke dalam kelompok perlakuan dengan masing-masing kelompok 40 lansia. Perlakuan yang diberikan suplementasi Fe (elemental besi $60 \mathrm{mg}$ ), perlakuan suplementasi kombinasi Fe+Zn (elemental besi $60 \mathrm{mg}$ dan Zn $20 \mathrm{mg}$ ) dan kontrol (mendapatkan placebo berisi amylum). Pemberian suplementasi dilakukan seminggu 2 kali dengan pemberian $\mathrm{Fe}$ dan $\mathrm{Zn}$ pada hari yang berbeda. Selama dalam proses penelitian 6 orang lansia mengundurkan diri 2 dari kelompok perlakuan kombinasi $\mathrm{Fe}+\mathrm{Zn}$ dan 4 pada kelompok kontrol sampai diakhir penelitian tinggal 36 lansia.

Data identitas subjek meliputi nama, umur, alamat dilakukan dengan wawancara. Data status kesehatan diperoleh dengan pemeriksaan fisik oleh dokter, kadar hemoglobin diperoleh dengan pemeriksaan laboratorium dengan metode cyanmethemoglobin. Untuk data asupan diperoleh dengan food record dan dianalisis dengan nutrisurvey.

Variabel bebas adalah pemberian suplementasi Fe, $\mathrm{Fe}+\mathrm{Zn}$, Variabel terikat adalah kesegaran jasmani, dan variabel antara adalah kadar hemoglobin. Untuk melaksanakan pengujian apakah ada peningkatan kadar hemoglobin dan kesegaran jasmani lansia setelah pelaksanaan intervensi serta perbedaan peningkatan kadar hemoglobin dan kesegaran jasmani lansia antara yang mendapat suplementasi Fe, kombinasi Fe dan $\mathrm{Zn}$ dan kelompok kontrol dan pengaruh intervensi suplementasi (Fe, kombinasi Fe dan Zn, dan kelompok kontrol) dan kadar hemoglobin terhadap kesegaran jasmani lansia digunakan uji Analisis Kovarian. Untuk melaksanakan pengujian hubungan antara kadar hemoglobin dengan kesegaran jasmani lansia digunakan dengan uji korelasi product moment dengan menggunakan bantuan komputer.

\section{HASIL DAN BAHASAN}

\section{Karakteristik Responden}

Karakteristik responden masing-masing kelompok perlakuan dapat diamati pada Tabel 1.
Umur responden berkisar antara 60-90 tahun, dan sebagian besar berumur antara 65-80 tahun baik pada kelompok perlakuan maupun pada kelompok kontrol $(59,8 \%)$. Sementara sisanya pada lansia muda atau di bawah 64 tahun $(29,8 \%)$ dan lansia lanjut atau 81 tahun ke atas $(10,4 \%)$.

Konsumsi gizi rata-rata secara umum pada responden masih di bawah kecukupan yang dianjurkan. Untuk kalori nilai rata-rata konsumsinya sebesar $65,02 \%$ Angka Kecukupan Gizi (AKG) untuk seluruh responden. Sementara kalau dilihat berdasarkan kelompok perlakuan rata-rata konsumsi kalori tertinggi ada pada kelompok perlakuan suplementasi kombinasi $\mathrm{Fe}+\mathrm{Zn}$ sebesar $68,10 \%$ AKG, baru disusul kelompok perlakuan suplementasi Fe 63,5\% AKG dan kelompok kontrol sebesar $63,47 \%$ AKG.

Pada penelitian ini rata-rata konsumsi protein untuk seluruh responden sebesar $72,10 \%$ AKG, dan pada masingmasing kelompok konsumsi tertinggi dicapai oleh kelompok perlakuan suplementasi kombinasi $\mathrm{Fe}+\mathrm{Zn}$ sebesar 73,13\% AKG, dan kelompok kontrol 72,53\% AKG baru kelompok perlakuan suplementasi Fe sebesar 70,75\% AKG.

Kebutuhan Fe untuk lansia menurutAngka Kecukupan Gizi yang dianjurkan untuk lansia adalah sebesar $13 \mathrm{mg}$ untuk pria, dan $14 \mathrm{mg}$ untuk wanita, hasil pengukuran yang dilaksanakan dalam penelitian ini diperoleh rata-rata konsumsi $\mathrm{Fe}$ dari seluruh responden baru mencapai 45,37\% AKG. Untuk masing-masing kelompok konsumsi Fe tertinggi justru dicapai oleh kelompok kontrol yaitu 46,33\% AKG, kelompok perlakuan Fe sebesar 43,85\%

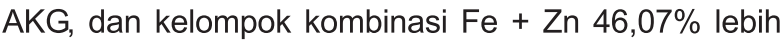
rendah konsumsi Fe-nya.

Tingkat konsumsi Vitamin C lansia secara keseluruhan baru mencapai 15,13\% AKG. Rata-rata konsumsi tertinggi dicapai oleh kelompok kontrol yaitu sebesar 19,42\% AKG, sedangkan pada kelompok suplementasi $\mathrm{Fe}$, dan kombinasi $\mathrm{Fe}+\mathrm{Zn}$ masing-masing baru mencapai $14,02 \%$ AKG dan 12,23\% AKG.

Konsumsi mineral $\mathrm{Zn}$ pada lansia menurut Angka Kecukupan Gizi yang dianjurkan untuk lansia sebesar $15 \mathrm{mg}$. Secara umum rata-rata konsumsi baru mencapai $60,38 \%$ AKG. Rata-rata konsumsi Zn pada kelompok perlakuan suplementasi Fe mencapai 56,65\% AKG, kelompok perlakuan suplementasi kombinasi $\mathrm{Fe}+\mathrm{Zn}$ mencapai $63,84 \%$ AKG, dan untuk kelompok kontrol sebesar $60,88 \%$ AKG.

Hasil penapisan lansia diperoleh angka anemia sebesar 52,29\%, angka ini tidak jauh berbeda dengan angka pada SKRT tahun 1995 di mana angka anemia pada lansia sebesar $59,8 \%$ pada laki-laki dan $49,8 \%$ pada perempuan.

Gambaran konsumsi pangan pada lansia dari hasil penelitian ini diperoleh angka yang masih jauh dari 
TABEL 1. Karakteristik dasar responden

\begin{tabular}{lccccc}
\hline \multicolumn{1}{c}{ Variabel } & $\begin{array}{c}\text { Kelompok } \\
\text { perlakuan I } \\
(\mathbf{n = 4 0 )}\end{array}$ & $\begin{array}{c}\text { Kelompok } \\
\text { perlakuan II } \\
\mathbf{( n = 3 8 )}\end{array}$ & $\begin{array}{c}\text { Kelompok } \\
\text { kontrol } \\
(\mathbf{n = 3 6 )}\end{array}$ & $\mathbf{F}$ & $\mathbf{p}$ \\
\hline Umur (tahun) & $71,30 \pm 8,92$ & $68,76 \pm 8,11$ & $70,00 \pm 7,49$ & 0,928 & 0,398 \\
Konsumsi energi & $63,50 \pm 25,83$ & $68,10 \pm 23,56$ & $63,47 \pm 21,90$ & 0,473 & 0,624 \\
Konsumsi Kh & $67,43 \pm 29,91$ & $75,82 \pm 29,03$ & $73,50 \pm 33,08$ & 0,781 & 0,460 \\
Konsumsi protein & $70,75 \pm 30,77$ & $73,13 \pm 38,91$ & $72,53 \pm 35,23$ & 0,049 & 0,952 \\
Konsumsi vit. C & $14,03 \pm 15,96$ & $12,24 \pm 12,57$ & $19,42 \pm 21,38$ & 1,796 & 0,171 \\
Konsumsi Zn & $56,65 \pm 22,62$ & $63,84 \pm 35,79$ & $60,89 \pm 24,87$ & 0,637 & 0,531 \\
Konsumsi Fe & $43,85 \pm 19,60$ & $46,07 \pm 19,57$ & $46,33 \pm 23,27$ & 0,167 & 0,846 \\
Kadar Hb (Gram/dL) & $10,96 \pm 0,65$ & $10,52 \pm 0,77$ & $10,76 \pm 0,93$ & 0,153 & 0,856 \\
Kesegaran jasmani & $0,75 \pm 0,21$ & $0,71 \pm 0,18$ & $0,75 \pm 0,19$ & 0,472 & 0,625 \\
(Km) & & & & & \\
\hline
\end{tabular}

Keterangan: $\alpha=0,05$ dan bila $p>0,05$ : tidak bermakna Konsumsi berdasarkan $\%$ AKG

kecukupan zat gizi yang dianjurkan. Seperti konsumsi kalori rata-rata baru mencapai $65,02 \%$ AKG, angka ini lebih rendah bila dibandingkan dengan hasil penelitian di Yogyakarta (3) konsumsi kalori rata-rata mencapai $70 \%$ AKG. Asupan protein sebagai bahan untuk membantu penyerapan zat besi pada ketiga kelompok penelitian masih rendah, rata-rata baru mencapai $72,10 \%$ AKG, asupan Vitamin C 15,13\% AKG, Zat Fe 45,37\% AKG, Zn $60,38 \%$ AKG. Rendahnya konsumsi gizi pada lansia dimungkinkan karena mulai turunnya fungsi organ-organ tubuh, terutama pada alat pencernaan. Menurunnya fungsi gigi geligi, turunnya fungsi indera pengecap menyebabkan keengganan lansia untuk makan. Melihat kenyataan bahwa sumber makanan zat besi dan zat lain (protein, $\mathrm{Zn}$ ) yang berkaitan langsung dalam pembentukan heme banyak terdapat pada sumber bahan makanan hewani, sementara pada pada penelitian ini berdasarkan Food Record ratarata lansia jarang mengkonsumsi bahan pangan hewani, untuk bahan makanan sumber protein, lansia lebih banyak yang mengandalkan dari bahan makanan tempe dan tahu daripada daging dan ikan. Hal ini juga akan mempengaruhi masukan zat $Z n$ yang diketahui banyak berasal dari bahan makanan bersumber bahan pangan hewani. Untuk sumber vitamin $\mathrm{C}$ sebagai pemacu penyerapan zat besi yang berasal dari buah-buahan jarang mereka konsumsi. Hasil ini tidak berbeda jauh dengan hasil penelitian pada lansia yang dilaksanakan oleh Dinas Kesehatan Propinsi DIY, Lansia di Kabupaten Bantul yang mengkonsumsi buah untuk setiap harinya sebesar $19,08 \%$ dari jumlah sampel 1050 lansia (7).

\section{Perbedaan Kadar Hemoglobin antara Kelompok Perlakuan Suplementasi Fe, Kombinasi Fe + Zn, dan Kontrol}

Gambaran perbedaan rata-rata kadar hemoglobin lansia antara kelompok perlakuan yang mendapat suplementasi Fe, Kombinasi Fe dan Zn, dan kontrol dapat dilihat pada Gambar 1.

Pada Gambar 1 dapat dilihat juga seberapa besar perubahan rata-rata kadar hemoglobin pada masingmasing kelompok. Pada kelompok perlakuan dengan suplementasi $\mathrm{Fe}$ dan $\mathrm{Zn}$ mengalami peningkatan ratarata kadar hemoglobin sebesar $1,09 \mathrm{~g} / \mathrm{dl}$. Hal ini lebih tinggi daripada 2 kelompok yang lain, yaitu kelompok perlakuan suplementasi Fe dengan peningkatan ratarata kadar hemoglobin sebesar 0,687 $\mathrm{g} / \mathrm{dl}$ dan pada kelompok kontrol sebesar 0,342 g/dl

Hasil perhitungan analisis Kovarians diperoleh nilai $\mathrm{p}=0,012$ yang berarti ada perbedaan kadar hemoglobin yang disebabkan oleh perlakuan antara kelompok yang mendapat suplementasi Fe, kombinasi Fe dan Zn, dan kontrol.

Selanjutnya untuk membuktikan pengaruh mana yang paling besar dari perlakuan terhadap perubahan kadar hemoglobin dilakukan uji pairwaise comparisons, di mana berdasarkan perbandingan nilai mean of differences kelompok Fe kontrol nilainya sebesar $0,405 \mathrm{~g} / \mathrm{dl}$ sementara pada kelompok $\mathrm{Fe}+\mathrm{Zn}$ kontrol nilai mean of differences sebesar 0,627 g/dl. Dari hasil uji statistik pada kelompok perlakuan $\mathrm{Fe}$ kontrol diperoleh nilai $\mathrm{p}=0,034$ sementara untuk perlakuan $\mathrm{Fe}+\mathrm{Zn}$ kontrol diperoleh nilai $p=0,004$, maka pengaruh perlakuan pemberian suplementasi $\mathrm{Fe}+$ $\mathrm{Zn}$ terhadap kadar hemoglobin lebih baik dibandingkan dengan perlakuan suplementasi Fe saja. Namun demikian dari hasil perhitungan dengan menggunakan rumus ini, perbedaan pengaruh perlakuan antara kelompok suplementasi $\mathrm{Fe}+\mathrm{Zn}$ dan kelompok suplementasi Fe tidak bermakna secara statistik $p=0,404$.

Kondisi lansia setelah 3 (tiga) bulan perlakuan menunjukkan adanya kenaikan rata-rata kadar hemoglobin pada masing-masing kelompok baik pada kelompok perlakuan suplementasi $\mathrm{Fe}$, kelompok perlakuan suplementasi kombinasi $\mathrm{Fe}+\mathrm{Zn}$ maupun kontrol, namun 


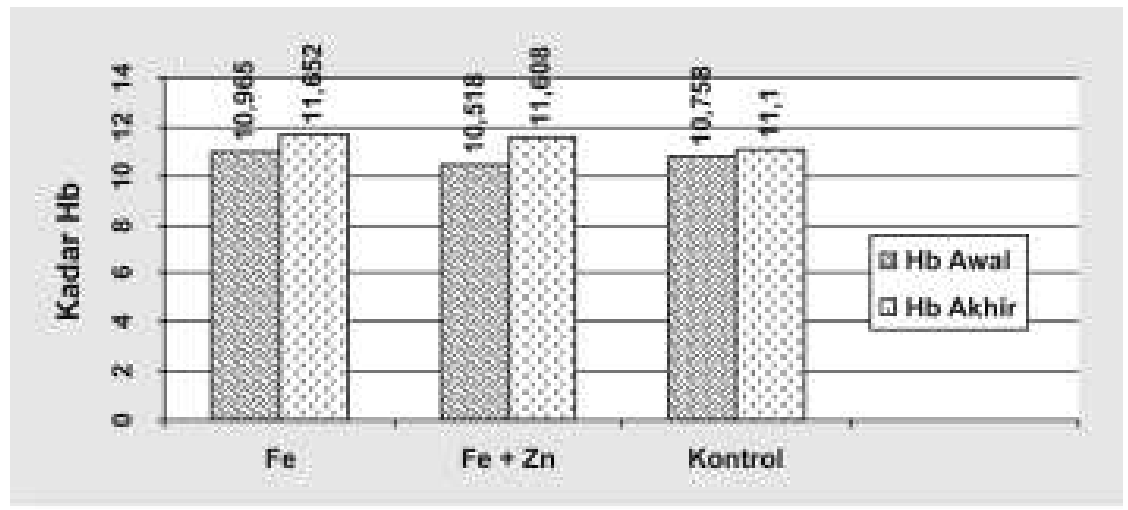

GAMBAR 1. Kadar Hb Lansia berdasarkan Kelompok Pertakuan

demikian kelompok yang paling tinggi rata-rata kenaikan kadar hemoglobinnya adalah kelompok perlakuan suplementasi Fe+Zn (1,09 g/dl). Hasil uji statistik kovarians terbukti bahwa ada perbedaan perubahan kadar hemoglobin antara kelompok yang mendapat suplementasi Fe, suplementasi $\mathrm{Fe}+\mathrm{Zn}$ dan kontrol yang disebabkan karena suplementasi dengan nilai $p=0,012$. Pada hasil uji statistik kovarians juga menunjukkan bahwa antara suplementasi $\mathrm{Fe}$ dan suplementasi kombinasi $\mathrm{Fe}+\mathrm{Zn}$ tidak ada
Peranan vitamin $\mathrm{C}$ dalam kaitannya dengan zat besi adalah sebagai enhancer yang kuat dalam mereduksi ferri menjadi ferro, sehingga mudah diserap dalam $\mathrm{pH}>3$ seperti yang ditemukan pada duodenum dan usus halus (8).

Selain vitamin C, enhancer lainnya yang cukup kuat adalah daging atau ikan dalam absorbsi zat besi. Daging mempunyai dua keuntungan dalam proses metabolisme zat besi, yaitu berisi heme iron yang mempunyai bioavibilitas tinggi dan bebas dari pengaruh komposisi makanan lain (9).

TABEL 2. Gambaran persentase perubahan kadar hemoglobin

\begin{tabular}{lcccccc}
\hline \multirow{2}{*}{ Kelompok perlakuan } & \multicolumn{2}{c}{ Hb naik } & \multicolumn{2}{c}{ Hb tetap } & \multicolumn{2}{c}{ Hb turun } \\
\cline { 2 - 7 } & $\mathbf{n}$ & $\mathbf{\%}$ & $\mathbf{n}$ & $\mathbf{\%}$ & $\mathbf{n}$ & $\mathbf{\%}$ \\
\hline Fe $(\mathrm{n}=40)$ & 36 & 90,0 & - & - & 4 & 10,0 \\
$\mathrm{Fe}+\mathrm{Zn}(\mathrm{n}=38)$ & 35 & 92,1 & 1 & 2,6 & 2 & 5,3 \\
Kontrol $(\mathrm{n}=36)$ & 20 & 55,5 & 3 & 8,3 & 13 & 36,1 \\
\hline
\end{tabular}

perbedaan yang bermakna ( $p=0,404)$. Hal ini berarti kedua perlakuan tersebut mempunyai efektivitas yang sama terhadap peningkatan kadar hemoglobin.

Kenyataan tersebut menunjukkan bahwa pemberian suplementasi kombinasi $\mathrm{Fe}+\mathrm{Zn}$ tidak lebih baik dibandingkan suplementasi Fe untuk menaikkan kadar hemoglobin. Beberapa faktor yang dapat menyebabkan terjadinya hal tersebut di atas adalah: 1) Suplementasi Zn tidak bisa dimanfaatkan secara optimal, seperti halnya zat besi dalam penyerapannya ada zat yang menghambat absorpsi Zn yaitu kalsium, fitat dan serat; 2) Masalah rendahnya kadar hemoglobin bukan hanya disebabkan karena asupan zat besi yang kurang, tetapi juga disebabkan oleh kekurangan unsur gizi yang lain yang mempunyai peranan pada sintesis heme, seperti rendahnya asupan vitamin C 15,1\% AKG, Zn 60,38\% AKG dan asupan protein $72,1 \%$ AKG, khusus untuk protein masih mengandalkan sumber dari protein nabati.
Unsur-unsur tersebut, dalam penelitian ini tingkat konsumsinya masih di bawah angka kecukupan yang dianjurkan, sehingga meskipun diberikan suplementasi Fe dan $\mathrm{Zn}$ namun zat lain yang turut berperan dalam sintesis heme tidak mendukung, maka perubahan kadar hemoglobin tidak akan optimal.

Meskipun kenaikan kadar hemoglobin belum optimal, bila dilihat secara individu pada masing-masing kelompok perlakuan, persentase responden yang kadar hemoglobinnya mengalami kenaikan dapat dilihat pada Tabel 2.

Data ini menunjukkan bahwa suplementasi Fe, kombinasi $\mathrm{Fe}+\mathrm{Zn}$ mampu memberikan kontribusi untuk memperbaiki kadar hemoglobin meskipun kenaikan masih relatif kecil. Hasil ini mungkin akan lebih maksimal apabila suplementasi didukung dengan pola pangan yang mengandung zat gizi lengkap dan seimbang. 


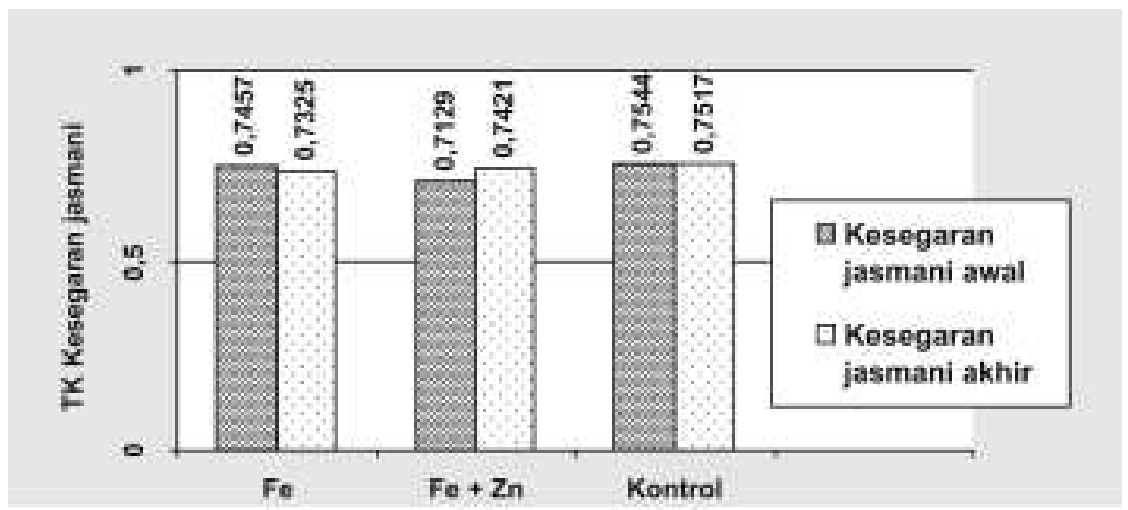

GAMBAR 2. Keseqaran Jasmani Lansia berdasarkan Kelompok Perlakuan

Perbedaan Kesegaran Jasmani Lansia Antara Kelompok Perlakuan Suplementasi Fe, Kombinasi $\mathrm{Fe}+\mathrm{Zn}$, dan Kontrol

Pada Gambar 2 terlihat bahwa hanya pada kelompok perlakuan pemberian suplementasi $\mathrm{Fe}+\mathrm{Zn}$ yang rata-rata kesegaran jasmaninya mengalami peningkatan sebesar 0,0292 km, meskipun peningkatannya relatif kecil. Sementara pada kelompok perlakuan pemberian suplementasi Fe dan kelompok kontrol mengalami penurunan rata-rata kesegaran jasmani. Pada kelompok perlakuan suplementasi $\mathrm{Fe}$ rata-rata penurunannya sebesar $0,013 \mathrm{~km}$ dan 0,0027 km pada kelompok kontrol.
Hasil pengukuran tingkat kesegaran jasmani setelah 3 (tiga) bulan perlakuan, menunjukkan bahwa peningkatan kadar hemoglobin pada kelompok perlakuan suplementasi kombinasi $\mathrm{Fe}+\mathrm{Zn}$ diikuti oleh kenaikan kesegaran jasmani lansia meskipun peningkatan relatif sangat kecil. Tidak demikian halnya untuk kelompok perlakuan suplementasi Fe dan kelompok kontrol, di mana pada dua kelompok ini kenaikan kadar hemoglobin tidak diikuti oleh kenaikan kesegaran jasmani, tapi justru mengalami penurunan meskipun penurunannya juga relatif sangat kecil. Perubahan kesegaran jasmani yang terjadi pada lansia berdasarkan hasil uji kovarians tidak menunjukkan perbedaan yang bermakna $(p=0,701)$.

TABEL 3. Gambaran persentase perubahan kesegaran jasmani

\begin{tabular}{lcccccc}
\hline \multirow{2}{*}{ Kelompok perlakuan } & \multicolumn{2}{c}{$\begin{array}{c}\text { Kesegaran } \\
\text { naik }\end{array}$} & \multicolumn{2}{c}{ Kesegaran tetap } & \multicolumn{2}{c}{$\begin{array}{c}\text { Kesegaran } \\
\text { turun }\end{array}$} \\
\cline { 2 - 7 } & $\mathbf{n}$ & $\%$ & $\mathbf{n}$ & $\%$ & $\mathbf{n}$ & $\%$ \\
\hline $\mathrm{Fe}(\mathrm{n}=40)$ & 16 & 40,0 & 7 & 17,5 & 17 & 42,5 \\
$\mathrm{Fe}+\mathrm{Zn}(\mathrm{n}=38)$ & 19 & 50,0 & 4 & 10,5 & 15 & 41,6 \\
Kontrol $(\mathrm{n}=36)$ & 15 & 41,6 & 1 & 2,7 & 20 & 55,5 \\
\hline
\end{tabular}

TABEL 4. Gambaran rata-rata perubahan kadar hemoglobin dan kesegaran jasmani

\begin{tabular}{lcccccc}
\hline \multirow{2}{*}{$\begin{array}{c}\text { Kelompok } \\
\text { perlakuan }\end{array}$} & \multicolumn{2}{c}{ Kadar hemoglobin (g/dL) } & \multicolumn{3}{c}{ Kesegaran jasmani (Km) } \\
\cline { 2 - 7 } \multicolumn{1}{c}{ Awal } & Akhir & Perubahan & Awal & Akhir & Perubahan \\
\hline $\mathrm{Fe}$ & 10,96 & 11,65 & 0,69 & 0,745 & 0,732 & $-0,013$ \\
$\mathrm{Fe}+\mathrm{Zn}$ & 10,51 & 11,60 & 1,09 & 0,712 & 0,742 & 0,03 \\
Kontrol & 10,75 & 11,10 & 0,35 & 0,754 & 0,751 & $-0,003$ \\
\hline
\end{tabular}

Hasil perhitungan statistik dengan rumus analisis kovarians menghasilkan nilai $p=0,701$. Hal ini berarti bahwa tidak ada perbedaan perubahan kesegaran jasmani lansia yang disebabkan oleh perlakuan antara kelompok perlakuan suplementasi Fe, kombinasi Fe + Zn, dan kelompok kontrol
Secara statistik angka perubahan kesegaran jasmani tidak menunjukkan perbedaan yang bermakna namun bila dilihat secara individu pada Tabel 3, nampak bahwa presentase lansia yang kesegarannya mengalami kenaikan, ada 50 lansia dari 114 lansia (43,86\%), 
terbanyak pada lansia yang mendapatkan suplementasi kombinasi Fe+Zn (19 dari 38 lansia atau 50\%). Salah satu kemungkinan yang terjadi, ada perbaikan fungsi $\mathrm{Zn}$ sebagai enzim di antaranya pada proses biosintesis heme. Dengan adanya masukan $\mathrm{Zn}$ akan mengaktifkan enzim ALA dehydratase yang berperan pada biosintesis heme, sehingga kemampuan pembentukan heme dapat optimal dan heme sebagai alat angkut oksigen yang dibutuhkan otot untuk pembentukan energi dapat tersedia. Metabolisme di mana Zn berperan berpengaruh pada kesegaran jasmani seseorang (10).

Sementara perbedaan persentase lansia yang kesegaran jasmaninya mengalami kenaikan antara kelompok suplementasi Fe dan kelompok kontrol relatif tidak berbeda.

\section{Hubungan Antara Kadar Haemoglobin dan Kesegaran Jasmani Lansia}

Gambaran rata-rata kadar hemoglobin dan kesegaran jasmani Lansia setelah 3 bulan perlakuan, dapat dilihat pada Tabel 4.

Untuk menguji ada tidaknya hubungan antara kadar Haemoglobin dan kesegaran jasmani lansia dilakukan uji statistik Korelasi Product Moment. Hasil uji statistik diperoleh nilai $\mathrm{p}=0,448$, dengan demikian tidak ada hubungan antara kadar hemoglobin dan kesegaran jasmani lansia.

Untuk mengetahui ada atau tidak adanya hubungan antara kadar hemoglobin dan kesegaran jasmani lansia, dilakukan uji korelasi. Berdasarkan hasil uji korelasi product moment, ternyata tidak menunjukkan adanya hubungan antara dua variabel tersebut di atas. $(p=0,448)$. $\mathrm{Hal}$ ini diperkuat lagi dengan hasil uji kovarians bahwa perlakuan dengan suplementasi $\mathrm{Fe}$, Kombinasi $\mathrm{Fe}+\mathrm{Zn}$ dan kadar hemoglobin tidak mempengaruhi kesegaran jasmani pada lansia. tus anemia lansia. Pada kondisi anemia keluhan fisik yang nyata adalah munculnya perasaan cepat lelah yang disebabkan oleh metabolisme atau pengolahan energi oleh otot tidak berjalan dengan sempurna karena ototkekurangan oksigen. Untuk menyesuaikan dengan berkurangnya pengiriman oksigen, maka otot membatasi produksi energi, akibatnya akan cepat merasa lelah karena kehabisan energi.

Kemungkinan yang lain, berkaitan dengan fungsi faali dan parameter metabolik. Fungsi faali dan parameter metabolik mengalami penurunan seiring dengan meningkatnya usia dan akan mengganggu utilisasi zat gizi (11).

Dalam penelitian ini, selaras dengan laporan yang disampaikan oleh Dinarto (11), subjek penelitian mempunyai rentang usia yang sangat lebar yaitu berumur antara 60-90 tahun. Rentang usia yang sangat lebar akan memberikan hasil yang berbeda bila dibandingkan kita mengambil subjek dengan rentang usia yang relative lebih pendek, misalnya 60-70 tahun.

Berdasarkan Tabel 5, bahwa lansia yang kadar hemoglobinnya dan kesegarannya naik terbanyak pada kelompok umur 60-70 tahun, baru kemudian diikuti oleh kelompok umur yang lain. Ini menunjukkan bahwa kemampuan pemanfaatan zat gizi dalam tubuh berkaitan dengan umur.

Bila dicermati lebih jauh lagi, bahwa lansia yang kadar hemoglobinnya naik dan diikuti kenaikan kesegaran jasmani pada kelompok umur antara 71-90 tahun, ternyata tingkat konsumsinya relatif lebih baik dibandingkan lansia yang kadar hemoglobin dan kesegaran jasmaninya tidak mengalami perubahan. Perbandingan tingkat konsumsinya seperti pada Tabel 6.

Hal ini bisa dimengerti bahwa dalam tubuh terdapat sistem pertahanan tubuh untuk melawan atau meredam radikal bebas. Sistem pertahanan tubuh tersebut

TABEL 5. Sebaran Lansia yang mengalami kenaikan hemoglobin dan kesegaran jasmani berdasarkan kelompok umur

\begin{tabular}{lccc}
\hline \multicolumn{1}{c}{ Kelompok umur } & $\begin{array}{c}\text { Kelompok } \\
\text { Fe }\end{array}$ & $\begin{array}{c}\text { Kelompok } \\
\text { Fe }+ \text { Zn }\end{array}$ & $\begin{array}{c}\text { Kelompok } \\
\text { komtrol }\end{array}$ \\
\hline $60-70$ tahun & 9 & 10 & 5 \\
$71-80$ tahun & 2 & 5 & 3 \\
$81-90$ tahun & 4 & 2 & 2 \\
\hline Total & 15 & 17 & 10 \\
\hline
\end{tabular}

Kemungkinan ini terjadi karena peningkatan kadar hemoglobin yang terjadi akibat perlakuan pemberian suplementasi Fe dan Zn relative kecil sehingga tidak cukup kuat untuk meningkatkan kesegaran jasmani pada lansia, karena peningkatan kadar hemoglobin belum merubah sta- didukung oleh zat gizi yang berfungsi sebagai antioksidan, yaitu suatu senyawa yang dapat meredam dampak negatif dari radikal bebas. Konsumsi makanan sumber vitamin dan mineral juga berarti menambah masukan antioksidan dalam tubuh. Hal ini juga berarti mengurangi jumlah radikal bebas yang terbentuk di dalam 
TABEL 6. Tingkat konsumsi Lansia berdasarkan Angka Kecukupan Gizi pada umur 71-90 tahun

\begin{tabular}{lcc}
\hline Zat gizi & $\begin{array}{c}\text { Tingkat konsumsi Lansia dengan } \\
\text { kenaikan Hb \& kesegaran jasmani } \\
\text { (\%AKG) }\end{array}$ & $\begin{array}{c}\text { Tingkat konsumsi Lansia tanpa } \\
\text { perubahan Hb \& kesegaran jasmani } \\
\text { (\%AKG) }\end{array}$ \\
\hline Karbohidrat & 72,14 & 67,56 \\
Protein & 77,55 & 72,1 \\
Vitamin c & 15,13 & 14,13 \\
Zn & 66,06 & 60,38 \\
Fe & 43,93 & 45,37 \\
\hline
\end{tabular}

tubuh. Sehingga kemampuan utilisasi zat gizi dapat dipertahankan, meskipun umur sudah di atas dekade-7, apabila mempunyai pola makan yang relatif baik (12).

Pengaruh Suplementasi (Fe, Kombinasi Fe+Zn) dan Kadar Hemoglobin terhadap Kesegaran Jasmani Lansia

Dari hasil uji Kovarians diperoleh nilai $p=0,941$. Hal ini berarti tidak ada pengaruh suplementasi (Fe, Kombinasi $\mathrm{Fe}+\mathrm{Zn}$ ) dan kadar hemoglobin terhadap kesegaran jasmani lansia. Hal ini sejalan dengan uji hipotesis pada saat pembuktian hubungan antara kadar hemoglobin dan kesegaran jasmani dengan uji korelasi, di mana dinyatakan tidak ada hubungan.

\section{KESIMPULAN DAN SARAN}

Dari hasil penelitian ini diperoleh hasil bahwa:

1. Ada perbedaan bermakna pada kenaikan kadar hemoglobin yang diakibatkan adanya perlakuan pada lansia antara yang mendapat suplementasi $\mathrm{Fe}$, kombinasi $\mathrm{Fe}+\mathrm{Zn}$ dan kontrol.

2. Tidak ada perbedaan yang bermakna pada kesegaran jasmani lansia yang diakibatkan adanya perlakuan antara yang mendapat suplementasi Fe, kombinasi $\mathrm{Fe}+\mathrm{Zn}$ dan control.

3. Tidak ada hubungan yang bermakna antara kadar hemoglobin dengan kesegaran jasmani pada lansia.

4. Ada pengaruh pemberian suplementasi Fe dan kombinasi Fe+Zn terhadap kenaikan kadar hemoglobin, namun pemberian suplementasi dan kenaikan kadar hemoglobin yang terjadi tidak berpengaruh terhadap kenaikan kesegaran jasmani lansia.

Perlu dilakukan penelitian yang sejenis, dengan subjek penelitian yang mempunyai rentang umur tidak terlalu lebar misalnya pada lansia yang berumur 60-70 tahun, 70-80 tahun dan seterusnya.
Perlu dilakukan pemeriksaan laboratories yang mendukung pemeriksaan klinis, untuk mendeteksi munculnya penyakit yang dapat mengganggu hasil penelitian (penyakit infeksi, perdarahan dalam tubuh).

Untuk mendapatkan hasil perbaikan kadar hemoglobin yang optimal, pemberian suplementasi perlu diikuti kegiatan penyuluhan tentang menu seimbang.

\section{RUJUKAN}

1. Utaryo C. Pemantapan Kemitraan Pembinaan Kesehatan Usia Lanjut. Yogyakarta; 2003.

2. Badan Penelitian dan Pengembangan Kesehatan. Survei Kesehatan Rumah Tangga 1995. Jakarta; 1997.

3. Husaini MA, Suharno D, Husaini J, Siagian U. Study Nutrition Anemia and Assesment of Information Compilation for Suporting and Formulating National Policy and Program. Jakarta: Direktorat Bina Gizi Masyarakat; 1989.

4. Smith DL. Anemia in the Elderly. Wisconsin: University of Wisconsin Medical School, Madison; 2000.

5. Soekirman. IImu Gizi dan Aplikasinya untuk Keluarga dan Masyarakat. Jakarta: Direktorat Jenderal Pendidikan Tinggi, Departemen Pendidikan Nasional; 2000.

6. Gillespie SR. Major Issues in the Control of Iron Deficiency the Micronutrien Initative. Canada: UNICEF; 1998.

7. Dinas Kesehatan Propinsi DIY. Laporan Penapisan Status Gizi Usila. Yogyakarta; 2002.

8. Fairweather, Susan J. Bioavailability of Iron, Iron Intervensions for Child Survival. London; 1995. p. 1330.

9. Svanberg. Dietary Intervensions to Prevent Iron Deficiency in Preschool Children. London; 1995. p.31-44

10. Murray, Robert K. Harper's Biochemestry. Amerika; 2000.

11. Dinarto M. Nutrisi pada Usia Lanjut. Jakarta; 2000. 